\title{
Durban Meeting of the South African Association for the Advancement of Science
}

$T^{n}$ HE thirtieth annual meeting of the South African Association for the Advancement of Science was held in Durban on July 4-9, under the presidency of Prof. P. J. du Toit. The meeting was very well attended and 117 papers were read. The South African medal and grant were presented to Prof. J. W. Bews and the first British Association medal to Dr. Nellie F. Paterson at the close of the presidential address. Popular evening lectures were given by General J. C. Smuts on "Climate and Man in South Africa" and by Prof. B. de St. J. van der Riet on "Essential Oils". There was a reception by the mayor and councillors and numerous excursions to places of scientific interest in the neighbourhood. [The papers presented at the meeting are now available as vol. 29 of the South African Journal of Science (Johannesburg: South African Association for the Advancement of Science, 1932. 30s. net).]

The presidential address on "Africa's Debt to Science" was delivered by Prof. P. J. du Toit. To illustrate what science has done for Africa, advances in preventive medicine and in veterinary science were considered in detail. Progress in the science of nutrition, including the rôle of vitamins and minerals for man and stock, was summarised and the interrelation of botanical and veterinary science indicated. Improvements in refrigeration and in communication were noted. What science can do for Africa in the future was indicated as increase in health, reduction of infantile mortality, eradication of diseases such as malaria and East Coast fever, organisation of native races and the development of large white dominions in Africa. According to Prof. du Toit, Africa should do much more to further research. The best use is not being made of either the money or the men available. Economy in brain power is necessary and men of great research capacity should not be wasted doing the work of junior clerks. Research should not be sacrificed for economy. Organisation of research is necessary and also the creation of conditions such that outstanding men can devote themselves to research.

Prof. R. W. Varder gave an account of recent work on "Particles and Waves" as his presidential address to Section $\mathbf{A}$. The quantum theory in relation to light and waves was discussed and the photoelectric and Compton effects were contrasted with de Broglie's views. 'The interference experiments of Thomson and their mathematical solutions, leading to the uncertainty principle of Heisenberg, were discussed. Quantum mechanics, radioactive decay and the structure of the atom in relation to modern spectral theory were also considered.

The presidential address to Section B, delivered by Dr. L. J. Krige, dealt with "The Geological History of Durban". After the deposition of the oldest existing South African rocks, included in the Swaziland and Pongola systems, intrusions of granite occurred. The earlier formations were afterwards denuded, and granite is the most ancient rock near Durban. Succeeding formations are not represented in Natal. Each of the old systems has a bed of tillite, indicative of arctic conditions, and the Dwyka ice age was the severest known. At the break-up of Gondwanaland the Cretaceous beds of Durban Bay were deposited. In the Pleistocene the Bluff Peninsula was built up and the sea level oscillated to $500 \mathrm{ft}$.
In post-Pleistocene times, sea level did not rise so high as in previous inter-glacials, but at its greatest height a spit was built from the Bluff to the mouth of the Umgeni River, which opened into the original Durban Bay. Its silting up formed the Durban flat and resulted in its present course to the sea. Sea level subsidence left the old alluvial flats above sea level and several rivers formed new flats. Remains of marine wave-cut terraces occur between the Bluff and the Umbogintwini River and mark its former position.

Prof. E. M. Robinson considered "The Development of Veterinary Bacteriology in South Africa" in his presidential address to Section C. The early work on bacteriology here was noted, then special diseases were considered. The work on anthrax, including immunisation, attenuation and methods of administration were described. The gas gangrene group includes the organisms of blackquarter and the various methods of treatment were described. The usefulness of formolised vaccines against $B$. welchii and $B$. cedematiens was noted. The work on contagious abortion due to $B$. abortus and Vibrio fatus, and the salmonelloses, of importance to the poultry industry, were discussed. Bovine tuberculosis is receiving attention; avian tuberculosis does not seem widespread. C. parabotulinum bovis, responsible for lamsiekte of cattle, was discussed and miscellaneous bacteriological conditions in domestic animals noted.

Dr. R. Broom spoke on "Evolution as the Palæontologist Sees It" in his presidential address to Section D. The hypotheses of Darwin and Lamarck were considered palæontologically. Evolution, said Dr. Broom, is not by large mutations but by almost imperceptibly slight modifications along definite lines, from small generalised forms to large highly specialised types, as is shown by a wealth of examples. The evolution of horns in fossil and modern forms was considered. Many structures that were useless developed in the past, and their owners were failures. Evolution is continuous, not backwards and forwards. About 99 per cent of all known fossil forms became specialised in some direction so that they could not adapt themselves and so perished. The Therocephalia remained small and generalised. By the middle of the Eocene all known mammalian orders were established, all small generalised types had specialised and hence no new orders of mammals could afterwards appear. The belief was expressed that a psychic and a cosmic force had been at work and that some force had restrained the specialisation of the primates, evolving a higher type of brain, and causing man to appear. As evolution has practically finished and cannot be repeated unless all higher life is wiped off the earth and a new start made, man may be the end to which some power has guided evolution.

The presidential address to Section E, by Miss D. F. Bleek, was entitled "A Survey of our Present Knowledge of Rockpaintings in South Africa". Four areas in southern Africa were delimited. The first comprises the western Cape Province, Cape Midlands and southern part of the eastern Cape Province. There are three subdivisions: the western, with pictures showing poor work, little grouping, few superpositions; the midland, with many group scenes, more superpositions and bichromes in the

No. 3295, VoL. 130] 
latest layer; the south-eastern, less developed and mostly monochromes. The second area comprises the north-east Cape Province and foothills of the Drakensberg in Basutoland, the Free State and Natal. Caves are crowded with pictures, there are numerous superpositions, group scenes are frequent and monochromes, bichromes and polychromes are numerous. Towards the north, rock engravings replace paintings, the best being in the Transvaal. The third area, between the Kalahari and the Atlantic, has poly. chromes and dressed human figures of a curious type not found in areas 1 and 2. The fourth area, Southern Rhodesia, has granite as rock background, monochrome animals standing quietly, trees and plants and two types of human bodies; the workers seem to have been some branch of Bushmen. Southward migrations of different branches of the race seem to have occurred, one degenerating in art as it went, the other developing a high state of perfection.

The Rev. Prof. J. du Plessis dealt with "Missions as a Sociological Factor" in his presidential address to Section F. The influence of early missions, before the colonial era began in 1884 , on the black races of Africa was considered. Before 1884, the influence of missions on the general social life of the African was in part destructive; witcheraft, poison ordeal, human sacrifice, etc., being banned. Hygiene, sanitation, clothing and housing, industry and agriculture were introduced. The educational methods of early days were open to criticism, since the English public school system was imposed on people to whom it was not applicable. Adoption of European methods of life and the social status given them by the missionaries alienated them from their people. The introduction of better food products and teaching of trades in the early days were commended. The missionary carried the gospel, but in his wake came the traders and the Government. These contacts meant change of the old social order, and the value of missions was that they enabled the native to make the transition from old to new without moral and social disaster. New culture must be grafted on the old stock of native life. Missions are still necessary as a permanent and not merely permissive factor in the evolution and uplift of the native races.

In Section A a paper was given on the determinantal properties of oblong matrices; astronomical papers dealt with the pulsation theory of Cepheid variation, Tempel's comet 1866 (1) of the Leonid meteors, and the parallax of Nova Persei, 1901. The definitions of mechanical quantities were discussed. A new type of continuously variable inductance of fixed resistance was described. A series of papers dealt with the Electricity Supply Commission, the cost of generating and distributing electricity and electrostatic capacity. Recent investigations on cosmic rays and on Wilson chamber experiments on $\delta$-rays were described, and a note on polarised light-stress apparatus was presented. Mechanical strength of aggregates, soil erosion and its prevention, and veld reclamation were subjects of discussion.

In Section $B$ there were several joint meetings with other sections. Papers of geological interest dealt with the problem of past climates and peculiar little rock basins at Isipingo, Natal. The essential oils of Empleurum serratulum and of certain veld bushes in the Cape Western Province were described, as was the chemistry of the roots of Arctopus echinatus, and a further contribution to knowledge of the medicinal springs of South Africa was made.

In Section $\mathrm{C}$ a number of papers of mycological interest dealt with Helminthosporium parasites of cereals and wild grasses, the genus Hemileia, of importance to coffee growers, aster wilt, South African Clavariæ, various new South African fungi, die-back in Pinus insignis and a fungal infection on a tsetse fly. Bacteriological papers were concerned with the Weil-Felix reaction in heartwater, the serological diagnosis of horse sickness and the distribution of Azotobacter in Transvaal soils. An ecological study of the wattle bagworm, involving the possibility of controlling the insect by salting the soil, was presented, while another paper dealt with the physico-chemical changes produced in soils by the addition of salt. A series of papers of much interest to agriculturists related to work on intensive grazing on veld, experiments with improved pastures in the coastal belt, the relation of fertiliser treatment to soil reaction under turf, a pasture study of grazing conditions on a Potgietersrust farm, and a regrouping of cultivated barleys, with suggestions on the classification of cultivated plants. A revision of the genus Lopholoena was given. Other papers dealt with the cytology of the pollen mother-cells of certain plants, the aims and requirements of the International Committee on plant sociology and phytopathological notes.

In Section D papers of much entomological interest dealt with the embryological development of Euryope terminalis, the early stages of some South African hesperids, the biocœnosis of the plant Gnidia laxa, the possibilities of combating wattle bagworm with insecticidal dusts, and the control of Glossina pallidipes. Embryological papers dealt with developmental stages in the skulls of geckos and the morphology of the skull of Hyperolius. Papers on the morphology and phylogenesis of the Pareiasauridæ were of interest to palæontologists. Protozoological papers dealt with new parasitic Protozoa, including new species of Isospora and Eimeria from snakes and fish, with the freshwater Rhizopoda from the Worcester District of the Cape, with new species of Nebela found in South Africa and with the rate of growth of gregarines. Testudo verreauxi was discussed as a study in variation. The ultra-violet content of South African sunlight and the effect of underground work on the erythrocyte count of miners were considered. The validity of the Polypedatidæ as an autonomous family of the Anura was considered from the detailed anatomy of a number of genera. The significance of seasonal egg production in predicting the yearly total was of much interest to farmers. Baboon crania from Cathkin Peak district were described. South African Ancylidæ and the occurrence of schistosomiasis at river mouths were discussed. Two papers of much interest and causing much discussion were given in joint meetings with other sections and dealt with biology in relation to modern civilisation and with glands in relation to personality.

Section E had papers mainly centring round prehistory and social anthropology. The prehistory of South Africa and western Europe, the Smithfield and Wilton industries, and the archæology of the Cathkin Peak district were discussed. Rock shelters and archæological sites at Isipofu near Durban and at Salisbury Commonage were described, and papers were given on prehistoric South African defences and the ancient forts at Penhalonga, Southern Rhodesia. Strandlooper middens and implements in Natal were described, the occurrence of true burins in the Cape Province was notified, and an account given of the South African cleaver or biseau. The origin and

No. 3295, Vol. 130] 
phallic character of conical and perforated stones were discussed. Some South African Bushman paintings and rock engravings were described, and the weathering of granite in relation to such paintings was considered. The Bantu potting industry and its impact on other native potting industries in South Africa were described. Of much interest were papers dealing with the history and distribution of the bow and arrow in South Africa, the name 'Hottentot' in the records of early travellers, and the drums of the Zulu. An extraordinary Nyasaland dance mask was described. Skeletal remains from a gold prospecting trench in the Matopos were, on the whole, considered to be of Bushman origin. The results of culture contacts on the Xosa and Pondo families were reviewed.

In Section F, economists discussed the relations of currency and capital, the economics of the hirepurchase system and the scope and method of business economics. Historical papers dealt with the influence of the tsetse fly on South African history, early South African rock inscriptions, early road administration in the Cape and mining in South Africa, and a defence of Sir Benjamin D'Urban was presented. Educationists discussed the present system of vocational training, an experimental scale for measuring the attitude of the white to the native, Freudian classification of the instincts and its application to some problems of civilisation. Basic English was recommended as a foundation for bilingualism. An interesting analysis of what becomes of boys after they have left school was given. A paper of outstanding social importance dealt with education and economic condition in relation to size of family, the results embodying analysis of such in connexion with nearly 50,000 families.

The next annual meeting of the Association will be held at Barberton, under the presidency of Dr. H. Spencer Jones, in July, 1933.

H. B. Fantham.

\section{The 'Butterfly' Map Projection}

$\mathrm{I}^{\mathrm{N}}$ NATURE of October 22 an account was given of the "Butterfly' Map Projection" devised by Mr. B. J. S. Cahill, of Oakland, California. To save space and to use one instead of three world maps, Mr. Cahill combined his three variants in one drawing which he referred to as a diagram. We regret, however, that the writer of the article in NATURE misconceived the diagram, so that his comments upon it misrepresent the character and value of the pro-
(1) The Orthogonal, Conformal or Orthomorphic Variant, a three-way continuum, rhombic type, for use mainly as an international meteorological base map from which local synoptic charts are cut, to be reassembled after isometrical data is added to form daily single weather maps in the interest of long range forecasting.

(2) The Authalic, Equivalent or Orthometric Variant, a land map for anthropogeographical,

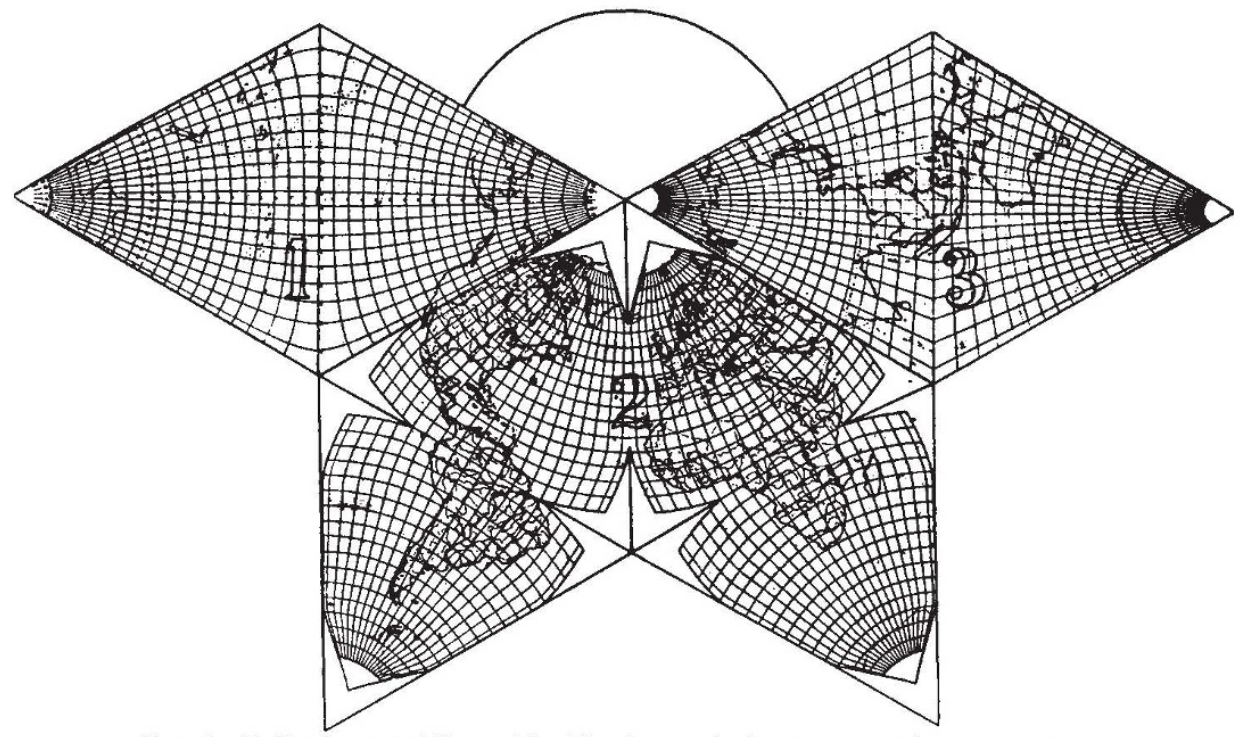

Fit. 1. Butterfly map of the world. The three variants are condensed to one diagram.

jection. In justice to Mr. Cahill we print below a condensed statement sent by him referring to the completion of the theory, tabulated computations and diagrams of his decentralised octahedral system of projection begun thirty years ago.

Earlier accounts published in Edinburgh 1909, Boston 1912, Gotha 1914, etc., describe a single 'maid-of-all-work' map now superseded by The Three Variants here condensed to one diagram (Fig. 1) and severally defined as to scientific quality and specific application as follows: statistical, economic, educational and general geosophical purposes.

(3) The Gnomonic, Central or Orthodromic Variant, with double tetrahedral extensions, for geodesic, navigational and geophysical problems of sea, land, air or 'ether'. The practically undistorted eight charts of this variant are to have full topographical details. Alternate sets of four of these charts are also enlarged by encroaching on onethird of the adjacent ones to cover the facets of right and left enveloping tetrahedrons, thus yielding two sets of reciprocally overlapping expansions of

No. 3295, VoL. 130] 